\title{
Antiquity, Exoticism, and Nature in Gold "Lotus and Dragon-fly" Comb with Cyprian Glass Fragment
}

\author{
Lauren Lovings-Gomez
}

Charles Baudelaire's Les Fleurs du Mal published in 1857 anthropomorphizes jewels as women in the poem "Les Bijoux." He writes of his naked lover adorned in jewels, describing his attraction to her, but perhaps more so to the jewels she wears. ${ }^{1}$ The jewels align with an ideal sense of feminine beauty, for parts of her body are compared to nature: "Her long legs, her hips, shining smooth as oil / Her arms and her thighs, undulant as a swan... / To her belly and breasts, the grapes of my vine." ${ }^{2}$ These not only refer to the sexuality of woman, but align her with natural elements often found in Art Nouveau jewelry. In Baudelaire's poem, there are evident ties to the fetishization of feminine beauty and the compulsion to identify that with organic forms in nature.

It does not seem coincidental that these notions are also rendered in objects. Created at the turn of the nineteenth century, Ornamental Comb (Figures 1 and 2), so named by the Cleveland Museum of Art, referred to as the CMA from this point forward, is a pastiche object of modernity evoking the ancient, exotic, and natural world through its materiality and design. ${ }^{3}$ In this paper, I aim to reconstruct the life of this object, with emphasis on its materiality. I argue that the centerpiece of ancient glass, framed in Art Nouveau ornamentation, transforms into a modern jewel in accordance with avant-garde notions of looking to the past to create something new. Finally, I will contend that decorative art objects, like the CMA's Ornamental Comb, disrupt the perceived hierarchy between what is deemed "high" and "low" art at the fin-de-siècle.

Ornamental Comb was created in partnership between a jeweler and a goldsmith. The object was designed by $\mathrm{F}$. Walter Lawrence, who was born in Baltimore in 1864, moved to Newark in 1880 to apprentice as a jeweler, and established

A special thank you to: Dr. Andrea Rager for supporting and challenging my research, Heather Galloway for giving me the opportunity write about this object, Colleen Snyder for taking the time to share her knowledge with me, and to Kylie Fisher for encouraging me to apply to the Florida State University Art History Graduate Symposium. This article is dedicated to my husband, Ruben Gomez.

1 Charles Baudelaire, Marthiel Mathews, and Jackson Mathews, The Flowers of Evil, (New York: New Directions, 1989), 27.

2 Baudelaire, et. al., The Flowers of Evil, 27.

3 Stephen Calloway, Lynn Federle Orr, and Esme Whittaker, The Cult of Beauty: The Victorian Avant-Garde, 1860-1900 (London: V\&A Publishing, 2011), 208. his own business in 1889. ${ }^{4}$ The comb was fabricated by the virtuoso goldsmith, Gustav Manz, who worked in the trade from 1893, when he emigrated from Germany to New York, until 1944. ${ }^{5}$ Though both artisans are not well-known today, they were prevalent in their lifetime. ${ }^{6}$ Lawrence and Manz specifically made the object for the 1904 World's Fair in St. Louis, where it would have likely been exhibited in the Palace of Fine Arts. This comb was among the twenty-five that Manz created for Lawrence for the exposition, and the only known piece still in existence. ${ }^{7}$ Clearly an esteemed object, the comb was also highlighted in a Town \& Country magazine article written by Lawrence in 1903 for using a fragment of "old glass, taken from the tombs throughout Syria, where it [had] lain for centuries" and in Vogue magazine in 1905 as part of a group of remarkable objects by Lawrence. ${ }^{8}$ In the Town \& Country article, Lawrence discusses the symbolism of his jewelry, stating "the real aim of L'Art Nouveau is to make something new, something beautiful, something that has meaning and history; and in making to accept such mediums as will best express the scheme or theme intended." ${ }^{\prime \prime}$ Lawrence aesthetically and intentionally chose to use the glass fragment's past to give meaning to its future, which I argue transforms into a modern jewel.

The CMA Ornamental Comb would have been worn in a woman's bound hair, and there were three common ways for a Victorian woman to wear a comb from about 1860 to 1900. A woman could wear a comb above her bound hair, so that the comb is seen frontally..$^{10}$ Another method is to wear the comb tucked into the back of the coiffure as an

4 "Obituary - F. Walter Lawrence," Summit Herald, March 12, 1929.

5 Courtney Bowers Marhev, "Where Credit is Due: The Life and Jewelry Work of Gustav Manz, 1865-1946" (Cooper-Hewitt, National Design Museum, Smithsonian Institution and Parsons The New School for Design, 2008), 1.

6 Marhev, "Where Credit is Due," 1.

7 Official Catalogue of Exhibitors. Universal Exposition, St. Louis, U. S. A. 1904. Division of Exhibits. Department B. Art. St. Louis: For the Committee on press and publicity, by the Official catalogue company, 1904, 82.

8 F. Walter Lawrence, "Symbolism in Jewelry," Town and Country 3004 (December 1903), 34; "Embellishing the Fragments," Vogue (June 22, 1905): 899. The comb was illustrated in the Town \& Country article, but not in the Vogue magazine article.

9 Lawrence, "Symbolism in Jewelry," 34.

10 Linda Setnik, Victorian Costume for Ladies: 1860-1900 (Atglen, PA: Schiffer, 2000), 28. 
embellishment. ${ }^{11}$ Lastly, bang combs were used on both sides of the parted hair line for flatter styles. ${ }^{12}$ Due to its long and narrow nature, Ornamental Comb was probably worn in the back of a woman's coiffure (Figure 3). On the verso above the stamped "F.W. Lawrence" (Figure 4), a hinge connects the tortoiseshell to the glass through the gold frame, which allows for bending and conforming to the coiffure. Since hairstyles usually remained the same throughout the day, the comb could have been worn with daytime and evening attire, presenting a varied effect with the changing light. ${ }^{13}$

The fragment of ancient glass incorporated into Ornamental Comb possesses a dynamic quality, as the colors completely transform under different angles of light. From one point, the glass appears as though ruby and copper have somehow melded together, while at another view it can look like an iridescent piece of emerald and obsidian. The 1904 Universal Exposition catalogue describes exhibit number 345 as "Gold 'Lotus and Dragon-fly comb with Cyprian glass fragment." 14 According to Lawrence in the object's entry form for the World's Fair, the glass fragment is "2,000 yrs. old found in tombs in the old City of Jerusalem." ${ }^{15}$ In The Craftsman from 1903 he states that archaeologist Ayeez Kayat found these glass fragments within the tombs of Jerusalem. ${ }^{16}$ Though there is no extant archaeological documentation, the glass is undoubtedly ancient. The rainbow-like iridescence of the ancient glass is not an intended effect, but ensues from the weathering process, which can be seen in an ancient Roman glass goblet from the CMA's collection (Figure 5). ${ }^{17}$ When ancient vessels or pieces of glass are obtained from archaeological digs, this iridescence usually appears to flake. After years of constant air and moisture contracting and expanding the layers of the glass, the laminate structure

11 Setnik, Victorian Costume, 31.

12 lbid., 145

13 Ibid., 20.

14 Official Catalogue of Exhibitors. Universal Exposition, St. Louis, U. S. A. 1904. Division of Exhibits. Department B. Art. St. Louis: For the Committee on press and publicity, by the Official catalogue company, 1904, 82. Twenty-five of the twenty-seven pieces shown were executed by Gustav Manz.

15 "These fragments of glass are parts of bowls, vases, tear-bottles and cups, found in tombs, in the ancient city of Jerusalem, and brought to this country by Ayeez Kayat, probably the greatest authority on ancient glass in the world, certainly, in this country." $\mathrm{F}$. Walter Lawrence, "Craftsmanship versus Intrinsic Value," The Craftsman 4 (June 1903): 182; Entry Form, "Information for Records, Applied Arts Division-Department of Art, St. Louis World's Fair," (1904) in Cleveland Museum of Art, Curatorial File, accessed April 5, 2018.

16 Karol B. Wight, Molten Color Glassmaking in Antiquity (Los Angeles: J. Paul Getty Museum, 2011), 5; F. Walter Lawrence, "Craftsmanship versus Intrinsic Value," The Craftsman 4 (June 1903): 182. It does seem that there was an established trade of ancient glass through Jerusalem that all became referred to as "Cyprian." However, it is problematic to consider the glass fragment as specifically "Cyprian" since there is no extant archaeological documentation in reference to the pieces brought by Kayat. Further, it is not feasible to classify glass vessels into regions of origin based on chemical content due to the fairly consistent nature of ingredients to make glass.

17 Catherine Hess and Karol Wight, Looking at Glass: A Guide to Terms, Styles and Techniques (Los Angeles: The J. Paul Getty Museum, 2005), 47. creates an iridescent quality. For this object, the iridescence was consolidated with an organic varnish, most likely applied by Lawrence or Manz. ${ }^{18}$ On the verso (Figure 2), the wavy ribbon of the glass's core is visible. CMA Conservator Patricia Griffin, estimates that "the fragment is from a coreformed opaque purple glass vessel decorated with combed and trail decoration in opaque white glass," perhaps similar to an ancient Greek perfume bottle from the Metropolitan Museum of Art (Figure 6). ${ }^{19}$

This ancient glass fragment in the comb is exoticized, originating in the Middle East, adapted by an American designer, and Orientalized through symbolic allusions of Egypt and Japan. The disparate nomination of the glass being from Syria, Cyprus, or ancient Jerusalem also demonstrates the nineteenth-century problematic amalgamation of all things from the "exotic east." Ornamental Comb is not the only object that Lawrence designed to incorporate ancient glass. He showed multiple works in 1903 that incorporated "Ancient Phoenician glass" in the Arts and Crafts Exhibition in Syracuse and Rochester, New York (Figure 7). ${ }^{20}$ Additionally, objects 336 to 345 in the official catalogue of exhibits for the St. Louis World's Fair in 1904 each have a "Cyprian" glass component. Lawrence was, in fact, quite intentional in his use of weathered, iridescent glass. In an article in The Craftsman, Lawrence comments that his compositions derive from the color and conformation of the fragments, while the designs derive from their excavation sites (Figure 7). ${ }^{21}$ Since, in the CMA's comb, the overall natural aesthetic is a common Art Nouveau design around the object's framework, it seems unlikely that Lawrence is referencing its excavation site, as he so explicitly does in the Egyptian forms illustrated in The Craftsman article. This reference and incorporation of the majesty of antiquity alone elevates the object beyond that of decorative art. The organic quality of the fragment's shape in the comb seems to suggest that the fragment was found and used largely without alteration. Moreover, a 1905 article in Vogue states that "Mr. Lawrence now buys the broken pieces of Cyprian and Egyptian glass in quantities and careful study of each fragment suggests to his artistic eye the one special design best adapted to its shape and coloring."22 Based on this Vogue article and Lawrence's remarks in The Craftsman, he, in all likelihood, used this fragment's elemental essence as the basis and inspiration for the design, adapting to its specific iridescent qualities.

18 Patricia Griffin, Conservation Department Loan Examination Report, Aug. 8, 2001 in CMA conservation file. Areas of loss in the varnish can be seen in the top proper left corner, and areas of varnish buildup can be seen in raking light on the top proper right corner and proper left. Further on the varnish, "examination of the surface in longwave ultraviolet light indicates a slight green fluorescence suggestive of a natural resin such as mastic or dammar that were commonly employed for paintings."

19 Griffin, Examination Report, Aug. 8, 2001. Core-formed glass is an early glass forming technique, before glassblowing.

20 At this point in my research, I have not uncovered whether any of these examples are extant.

21 F. Walter Lawrence, "Craftsmanship versus Intrinsic Value," The Craftsman 4 (June 1903): 183.

22 "Embellishing the Fragments," Vogue (June 22, 1905): 899. 
In the nineteenth century, a romanticizing of the ancient world and the emergence of glass from excavated sites of antiquity cultivated the desire for artists to test the possibilities of glass color and texture. ${ }^{23}$ In 1873, Louis Comfort Tiffany began experimenting to recreate the iridescent aesthetic of ancient Roman glass (Figure 8 ). ${ }^{24}$ Whereas ancient glass has the iridescent effect at the surface, Tiffany's iridescence was within the glass, essentially creating a new process to achieve what age does naturally. This favrile glass was praised at the 1900 Exposition Universelle in Paris, increasing this desire of replicating the aesthetic of old glass. ${ }^{25}$ Leslie Hayden Nash, Tiffany's Production Manager, describes the public's reaction to favrile glass when it was first displayed in the showrooms as everyone being "completely overcome and speechless at the sight. It gave one a feeling of sitting out in the tropical sun. It was literally a fairyland." ${ }^{26}$ This reaction reinforces the jewel-like status and effect of the iridescence of ancient glass desired by the public. Whereas Tiffany's studio focused on innovations in the creation of new glassmaking techniques to recreate this aesthetic, Lawrence continued to experiment with the use of ancient fragments, prized for their authenticity, sense of historicism, and rarity.

Mimicking the organic quality of the ancient glass, wavy golden vines wrap around the glass fragment, framing it like a small painting (Figure 1). Attached to these golden vines are lotus pads, lotuses in bloom and bud form (Figure 9), and a dragonfly hovering over the glass, which is encrusted with white and green gemstones on the edge of each wing (Figure 10). Though Lawrence does not explicitly reference icons of ancient Egypt as he did in the objects from The Craftsman article, he does provide symbolic allusions to the culture. The lotus (Figure 9), referencing antiquity and the exotic through its extensive use in ancient Egypt, was the symbol of reproductive power and fertility since it grew upon the generative Nile. ${ }^{27}$ Not only can this relate to Lawrence's intent to gather glass from the ancient Near East, it references the geographical region in which the glass fragments were sourced, and begins to call forth notions of the direct con-

23 "Glass vessels from ancient Rome, the Islamic world, Venice, and Bohemia stimulated the public's appetite for novel forms, colors, textures, and decorations, and glassmakers, including Tiffany, copied them to meet the growing demand." Alice Cooney Frelinghuysen, "Louis Comfort Tiffany at the Metropolitan Museum of Art," Metropolitan Museum of Art Bulletin (Summer 1998): 53.

24 Martin Eidelberg, Nancy A. McClelland, Leslie Hayden Nash, and Arthur Nash. Behind the Scenes of Tiffany Glassmaking: The Nash Notebooks: Including Tiffany Favrile Glass (New York: St. Martin's Press, 2001), xiii.

25 Alastair Duncan, Louis Comfort Tiffany (New York: Harry N. Abrams, Inc., Publishers, 1992, 87. Tiffany did, however, trademark Favrile glass on November 13, 1894, perhaps forcing Lawrence to turn to ancient glass fragments.

26 Martin Eidelberg, et al. Behind the Scenes of Tiffany Glassmaking: The Nash Notebooks: Including Tiffany Favrile Glass, 48.

27 Ernst Lehner and Johanna Lehner, Folklore and Symbolism of Flowers, Plants and Trees (New York: Tudor Pub. Co., 1960), 35. nection that exists between nature and femininity. ${ }^{28}$ Thus, the use of the lotus, a symbol of fertility, in an object meant for a woman creates a deeper significance of the materiality unifying the exotic, natural, and antique facets. In further exploration of the natural elements of the comb, dragonflies (Figure 10) as figural motif in Art Nouveau jewelry were favored for their short life spans and iridescence, which were symbols for metamorphosis and ephemerality. ${ }^{29}$ Here, their iridescence in nature refers back to that of the ancient glass fragment. Furthermore, their chitinous wing structure is layered into multiple plates, just as the ancient glass is to create its colorful iridescence. The encrusted gemstones contribute to the qualities of nature by eliciting the shimmer of a dragonfly's wings.

Yet another exotic material is the tortoiseshell. The materiality of the tortoiseshell comb activates a conversance through nature, antiquity, and exoticism. Tortoiseshell is a remarkably light, precious material, and was considered a luxury product, particularly prized for use in combs throughout the nineteenth century. ${ }^{30}$ In addition to their stunning aesthetic quality, tortoiseshell has anti-electrical properties, an ideal quality for hair combs. ${ }^{31}$ The tortoiseshell from this comb most likely comes from the Hawksbill turtle, often a habitant of Southeast Asia, China, and Japan, reinforcing the perception of exoticism in the comb. ${ }^{32}$ According to American marine biologist, Richard Ellis, "the supportive shell of a turtle is composed of hard, bony plates covered by individual horny segments known as scutes, which are made of keratin, the material of fingernails, hooves, and hair." ${ }^{\prime 33}$ Therefore, this is an object, made from the stuff of one species' hair, meant to be used in the hair of another species. Accordingly, the natural material of the object conforms to the wearer's own physical substance. Unfortunately, the implications indicate a predation relationship. The predator, or wearer, benefits from the natural properties at the detriment of the prey,

28 Tamar Garb, "Renoir and the Natural Woman," The Expanding Discourse: Feminism and Art History, Norma Broude and Mary D. Garrard, eds (Harper Collins, 1992), 295. In a previous paper, I have explored Garb's ideas of the woman's body becoming a "natural extension" of nature, since "women's very physiology was seen to be closer to nature than men's." Scholars and doctors at the time theorized that since women menstruate, they are in a constant state of instability, as is nature.

29 Hermann Schadt and Ann Potter Schadt, Goldsmiths' Art: 5000 Years of Jewelry and Hollowware (Stuttgart: Arnoldsche, 1996), 171.

30 Lison de Caunes, Jacques Morabito, and Johannes von Saurma, L'Écaille (Dourdan: H. Vial, 1997), 6, 8.

31 Caunes, et al. L'Écaille, 15. It became much easier to form tortoiseshell from its raw plates in the nineteenth century. First, the craftsman would draw an outline on the tortoiseshell and cut it out. Then, the fat was removed from the workable piece. Often, other pieces were fitted together using a hydraulic press to create thickness. In order to make the piece flexible, the shell was then plunged into boiling salted water. Next, a machine was used to cut the teeth of the comb. To conform to the lady's hair, a curve was given to the comb by using additional hot salt water. Finally, the comb was polished using a grindstone.

32 Caunes, Morabito, and von Saurma, L'Écaille, 19-20.

33 Richard Ellis, The Empty Ocean Plundering the World's Marine Life (Washington D.C.; Covelo; London: Island Press/Shearwater Books, 2003), 94-95. 
or tortoise. ${ }^{34}$ This perhaps recalls Baudelaire's predatorial descriptions of his lover, as the poem ends with her amber colored skin drenched in blood. ${ }^{35}$

While Lawrence and Manz were in dialogue with Tiffany, they would also have been responding to the work of French jeweler, René Lalique, especially for his innovations in jewelry design and use of materials. Manz left Germany to attend the 1889 Exposition Universelle in Paris to view jewelry designs, where he would have certainly seen the work of René Lalique. ${ }^{36}$ Lalique was paving the path for jewelry to transform from its precious gemstone focus, to fluid objects that reconnected wearable art to nature. He did so by completely turning to different, unthinkable materials, such as horn and semi-precious stones for their shape, color, and texture. ${ }^{37}$ Lalique would have also encountered Baudelaire's Les Fleurs du Mal, in which Baudelaire explored themes of eroticism and vice, often using women as his principal source of symbolism. Lalique absorbed these ideals of antiquity superiority into his quest to create avantgarde jewelry. He began to carve combs in horn and ivory in 1897, preferring the translucence, color, and malleability of the material allowing him to render natural subjects. ${ }^{38}$ In the CMA collection, René Lalique's Lily of the Valley Comb (Figure 11) is displayed alongside Lawrence and Manz's comb. In particular, they share a similar approach to floral imagery, allusions to nature, the typical Art Nouveau curvature, and use of horn material. ${ }^{39}$ Art Nouveau jewelers were employing the material to their advantage, and it is evident that for these jewelers, subject, form, and execu-

34 The exploitative use of tortoiseshell in art and decorative objects is rife with the fact that human desire has contributed to the rapid decline of the species, which, as of 1970, has been considered critically endangered: "Hawksbills are highly desired for their beautiful shells, which are polished and hung on the wall as a decorative ornament, or the scutes from their shells ('bekko') used to craft jewelry, combs, and eyeglasses... Commercial exploitation has resulted in overharvesting and in declines or local extinctions of the populations harvested." Peter L. Lutz, John A. Musick, and Jeanette Wyneken The Biology of Sea Turtles (Boca Raton, FL.: CRC Press, 1997), 402-403.

35 The materiality of the tortoiseshell can also recall amber fossils, reflecting this idea of ancient, exotic, and natural qualities within the object. Further, "turtles represent a separate group of vertebrates, and one of the oldest of all continuous vertebrate lineages, dating to the Middle Triassic period, about 230 million years ago." The tortoiseshell of the comb thus collaborates within all spheres of antiquity, exoticism, and nature through its materiality. Richard Ellis, The Empty Ocean Plundering the World's Marine Life (Washington D.C.; Covelo; London: Island Press/Shearwater Books, 2003), 93.

36 Courtney Bowers Marhev, "Where Credit is Due: The Life and Jewelry Work of Gustav Manz, 1865-1946" (Cooper-Hewitt, National Design Museum, Smithsonian Institution and Parsons The New School for Design, 2008), 11-12.

37 Yvonne Brunhammer, René Lalique: Exceptional Jewellery 1890-1912: [exhibition, Paris, Musée Du Luxembourg, 7 March 2007-29 July 2007] (Milano: Skira, 2007), 70.

38 Brunhammer, Lalique, 25, 73.

39 "Horn is a tough fibrous epidermal substance that consists chiefly of keratin, an albuminoid found in hoofs, nails, tortoiseshell, feathers, and hair...The horn of antelope, bison, buffalo, caribou, cow, deer, elk, goat, ibex, moose, ox, reindeer, sheep, and rhinoceros can all be used... Horn is relatively light in weight, and attractively warm to the touch and on the skin." Oppi Untracht, Jewelry Concepts and Technology (Garden City, N.Y: Doubleday, 1982), 558. tion originated in nature. ${ }^{40}$ In thinking of how Lawrence and Manz's comb references the natural exotic, Lalique's use of nature in jewelry, references the trickling in of Japanese objects into Europe from earlier international exhibitions. ${ }^{41}$ Further, plants from Japan came to Europe during the late nineteenth century, filling nurseries and botanical gardens, creating a horticultural boom which manifests through the lotus motif in the CMA comb. ${ }^{42}$

Though many of Lalique's objects focus on the nature of flora and fauna, he was also innovative in using the female form in jewelry. ${ }^{43}$ While Lawrence drew subtle connections between woman and nature, Lalique very explicitly morphed woman with nature. It is possible that Lalique was thinking about the Symbolist literary movement, specifically Baudelaire, in conjunction with the aesthetic of the female form at the fin-de-siècle. ${ }^{44}$ For example, he creates multiple variations of a winged woman broach. In one version (Figure 12), the figure is a hybrid dragonfly-woman, her head and bare chest are her only human remnants emerging from the enamel insect body and wings. The motif of the winged woman was strongly associated with Symbolists, as she was considered the epitome of the spirit of human and animal. ${ }^{45}$ Not only was Lalique looking to blur the lines of human and animal, he wanted to push the boundaries of what jewelry women would wear. Accordingly, Lalique's wearable objets $d^{\prime}$ art, were worn by great and daring women of the stage, such as actress Sarah Bernhardt. ${ }^{46}$ Ultimately, this exemplifies that Lalique was creating for the new woman, with woman simultaneously becoming the object and subject of his jewelry. Even so, by wearing this type of jewelry, these daring women were reclaiming their agency. ${ }^{47}$

Women were not only wearing hair combs, I claim that they started to be associated with them at the turn of the century. Around 1903, the Société Industrielle de Photographie produced a series of postcards called "Les Bijoux" in which photographs of women by Leopold Reutlinger are set

40 Emmanuel Ducamp, "France: The Ascendancy of Lalique" in Artistic Luxury: Fabergé, Tiffany, Lalique, ed. Stephen Harrison (Cleveland: Cleveland Museum of Art, 2008), 114.

41 Yvonne Brunhammer, René Lalique: Exceptional Jewellery 1890-1912: [exhibition, Paris, Musée Du Luxembourg, 7 March 2007-29 July 2007] (Milano: Skira, 2007), 152. Japanese plants arrived to London in 1862 and Paris in 1867.

42 Brunhammer, Lalique, 152-160.

43 Emmanuel Ducamp, "France: The Ascendancy of Lalique" in Artistic Luxury: Fabergé, Tiffany, Lalique, ed. Stephen Harrison (Cleveland: Cleveland Museum of Art, 2008), 126.

44 Ducamp, "France," 127.

45 Yvonne Brunhammer, René Lalique: Exceptional Jewellery 1890-1912, 134.

46 Brunhammer, Lalique, 88.

47 Emmanuel Ducamp, "France: The Ascendancy of Lalique" in Artistic Luxury: Fabergé, Tiffany, Lalique, ed. Stephen Harrison (Cleveland: Cleveland Museum of Art, 2008), 85, 130. 
within pieces of jewelry. ${ }^{48}$ In one example (Figure 13), the postcard depicts a woman wearing a strapless dress, with hands above her flower-crowned head holding a cloth that drapes down her back. She is turned slightly and stares off into the distance. Her image is the centerpiece to what is labeled "Peigne Ecaille \& Or" or "Shell Comb and Gold." Whereas the comb by Lawrence and Manz frames a piece of ancient glass, the decorative flowers and vines surround the image of the woman, framing her within the comb, and connecting her to the shell of the comb. Further, the flowers framing her image mimic the flowers placed in her hair, while the curving vines mirror the curves of her raised arms. She does not seem to wear a comb; however, she is framed within the comb, becoming a part of it. She symbolizes that women become the jewelry that they wear, and they themselves become ornamental. Since the postcards would have been produced after the Lawrence and Manz hair comb, I contend that the postcard producers were engaging not only with the fashion of this period, but also with what artists were crafting. Women appearing on postcards in the late nineteenth century were idealized, their exemplary image spread to millions as a result of photography, for the male buyers who were able to privately consume them due to the convenient portable size. ${ }^{49}$ Not only were they consumed, but surely collected in albums filled with other women alike. Therefore, the feminine object of the comb, seemingly turns the woman into an object via the photographic postcard, creating a tension between women choosing to wear this ornament with the consequential male gaze.

Overall, Lawrence and Manz's Gold "Lotus and Dragonfly" Comb with Cyprian Glass Fragment, its original and more appropriate name, is exceptional for its ambitious incorporation of multiple precious materials: gold, gemstones, tortoiseshell, but especially ancient glass, raising it to a high status of art. Ultimately, this comb is more than a piece of jewelry; it breaks the boundary between the ancient and the modern. It is not only a natural extension of a woman's hairstyle, it symbolically connects nature and femininity. It does not only assert authenticity through its excavated ancient glass fragment, but it looks to antiquity to elevate the glass, creating a new conception of the modern jewel. The Lawrence and Manz hair comb communicates the contemporary features

48 La Belle Otero Sous L'objectif De Reutlinger: Buch (Monaco: Ed. du Compas, 2005), 9-10; Jean P. Bourgeron, Les Reutlinger: Photographes À Paris 1850-1937 (París: Jean-Pierre Bourgeron, 1979), 33. Reutlinger first edited these postcards himself, but the demand grew exponentially, and he sought the help of additional distributors, such as la Société Industrielle de Photographie. In 1970, his son, Francois, republished the series of postcards.

49 Serge Zeyons, La Femme En 1900: Les Années 1900 Par La Carte Postale, (Paris: Larousse, 1994), 7. of its time, alluding to the exotic world, while also attempting to refabricate the beauty of antiquity and nature. Through its materiality, this comb is linking art to life. Through its design, the comb generates later commentary on feminine objectification. 


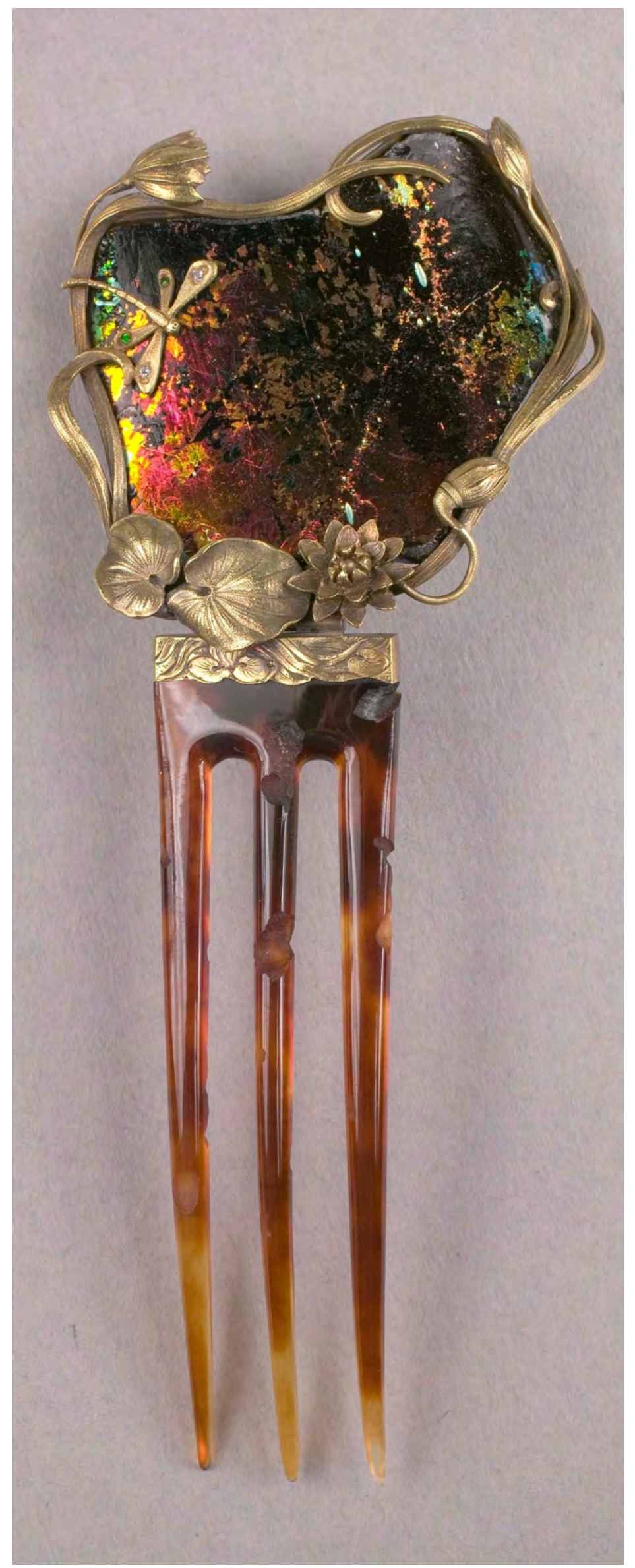

Figure 1. F. Walter Lawrence (American, 1864-1929) and Gustav Manz (German, 1865-1946), Ornamental Comb, c. 1900, gold, ancient glass, gem stones, tortoiseshell, overall: $14.3 \times 5.8 \times 1.9 \mathrm{~cm}$ (5 5/8 $\times 25 / 16 \times 3 / 4$ in.). The Cleveland Museum of Art, Gift of the Trideca Society 2001.106. Photo credit: Courtesy of The Cleveland Museum of Art, Conservation Department. 
Figure 2. F. Walter Lawrence (American, 1864-1929) and Gustav Manz

(German, 1865-1946), Ornamental Comb (verso), c. 1900, gold, ancient glass, gem stones, tortoiseshell, overall:

$14.3 \times 5.8 \times 1.9 \mathrm{~cm}(55 / 8 \times 25 / 16 \times$ $3 / 4$ in.). The Cleveland Museum of Art Gift of the Trideca Society 2001.106. Photo credit: Courtesy of The Cleveland Museum of Art, Conservation Department.

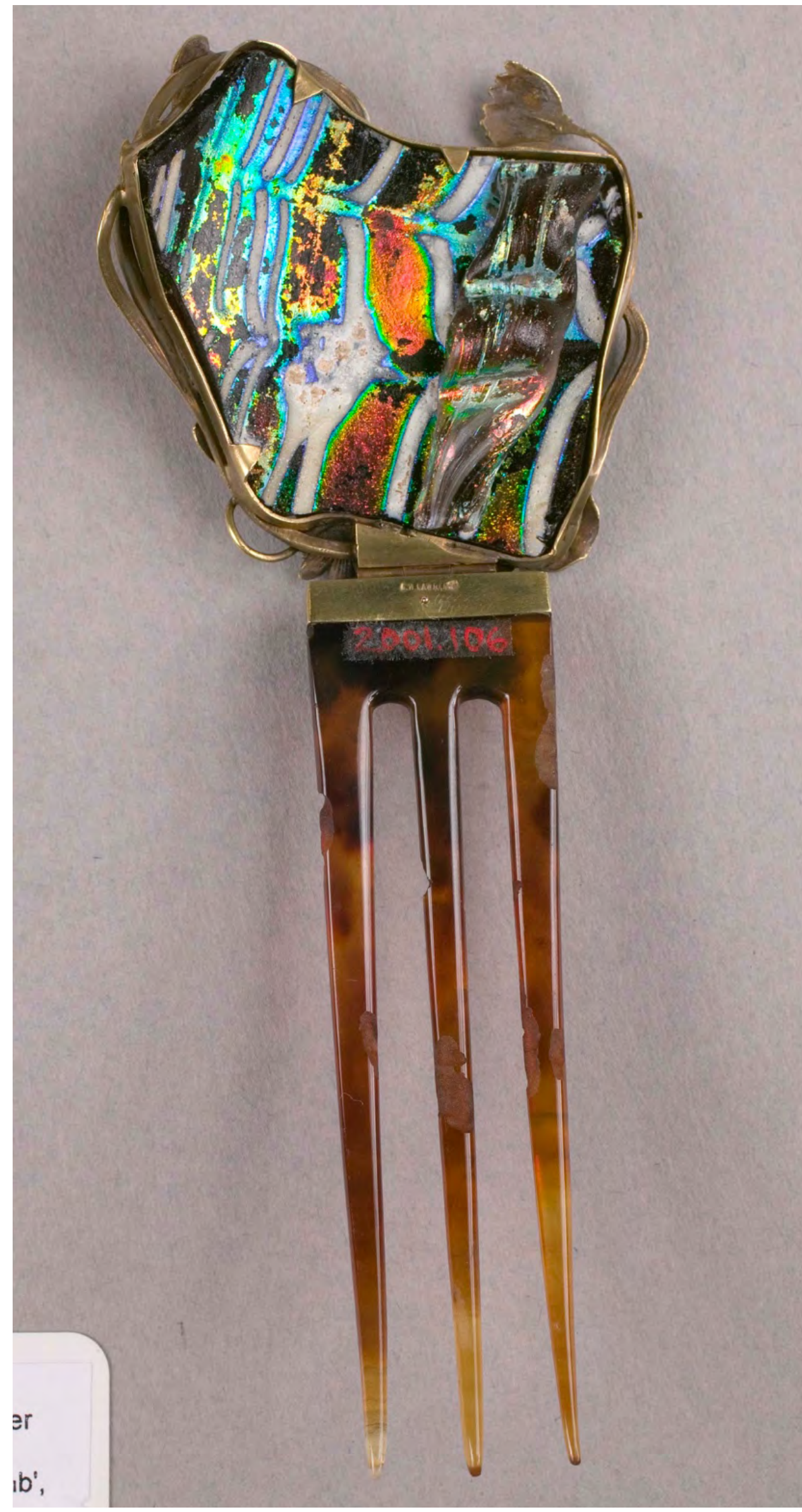




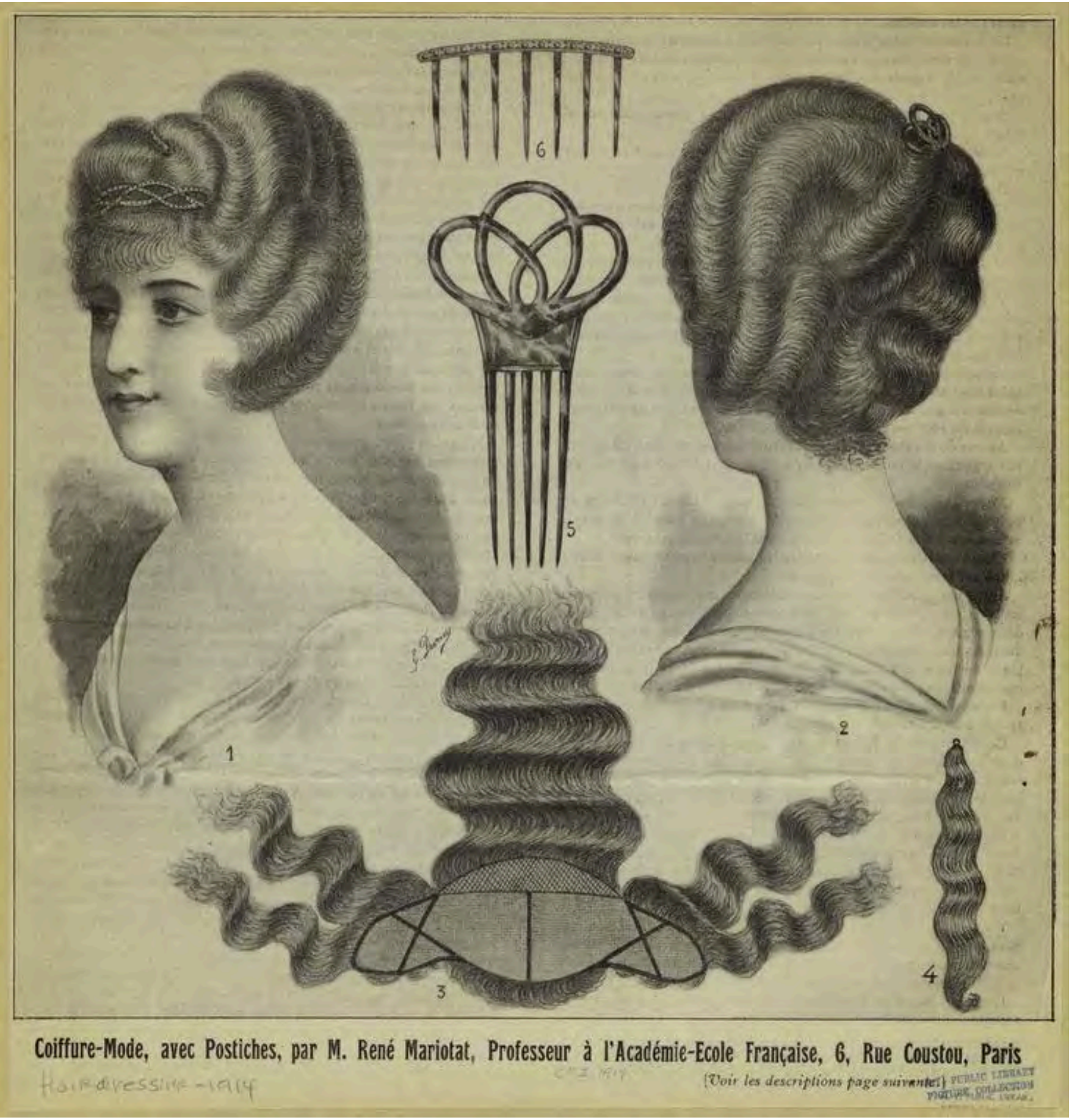

Figure 3. Art and Picture Collection, The New York Public Library, "Coiffure-Mode, Avec Postiches," New York Public Library Digital Collections, Accessed May 11, 2019. http://digitalcollections.nypl.org/items/510d47e1-0824-a3d9-e040-e00a18064a99 


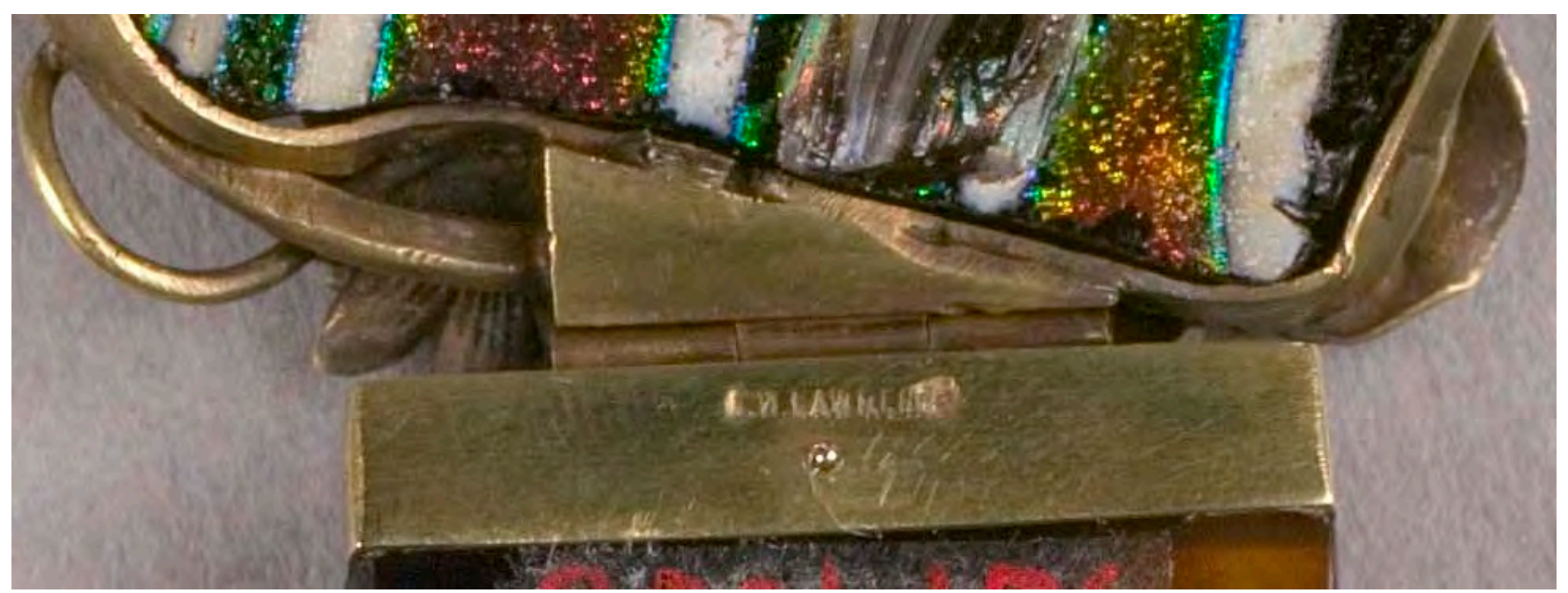

Figure 4. F. Walter Lawrence (American, 1864-1929) and Gustav Manz (German, 1865-1946), Ornamental Comb (detail), c. 1900, gold, ancient glass, gem stones, tortoiseshell, overall: 14.3 × 5.8 × $1.9 \mathrm{~cm}$ (5 5/8 × 2 5/16 × 3/4 in.). The Cleveland Museum of Art, Gift of the Trideca Society 2001.106

Photo credit: Courtesy of The Cleveland Museum of Art, Conservation Department.

Figure 5. Roman, Goblet, 100-300, glass, overall: 9 × 8.4 cm (3 9/16 x 3 5/16 in.). Cleveland Museum of Art, Gift of J. H. Wade 1923.953.

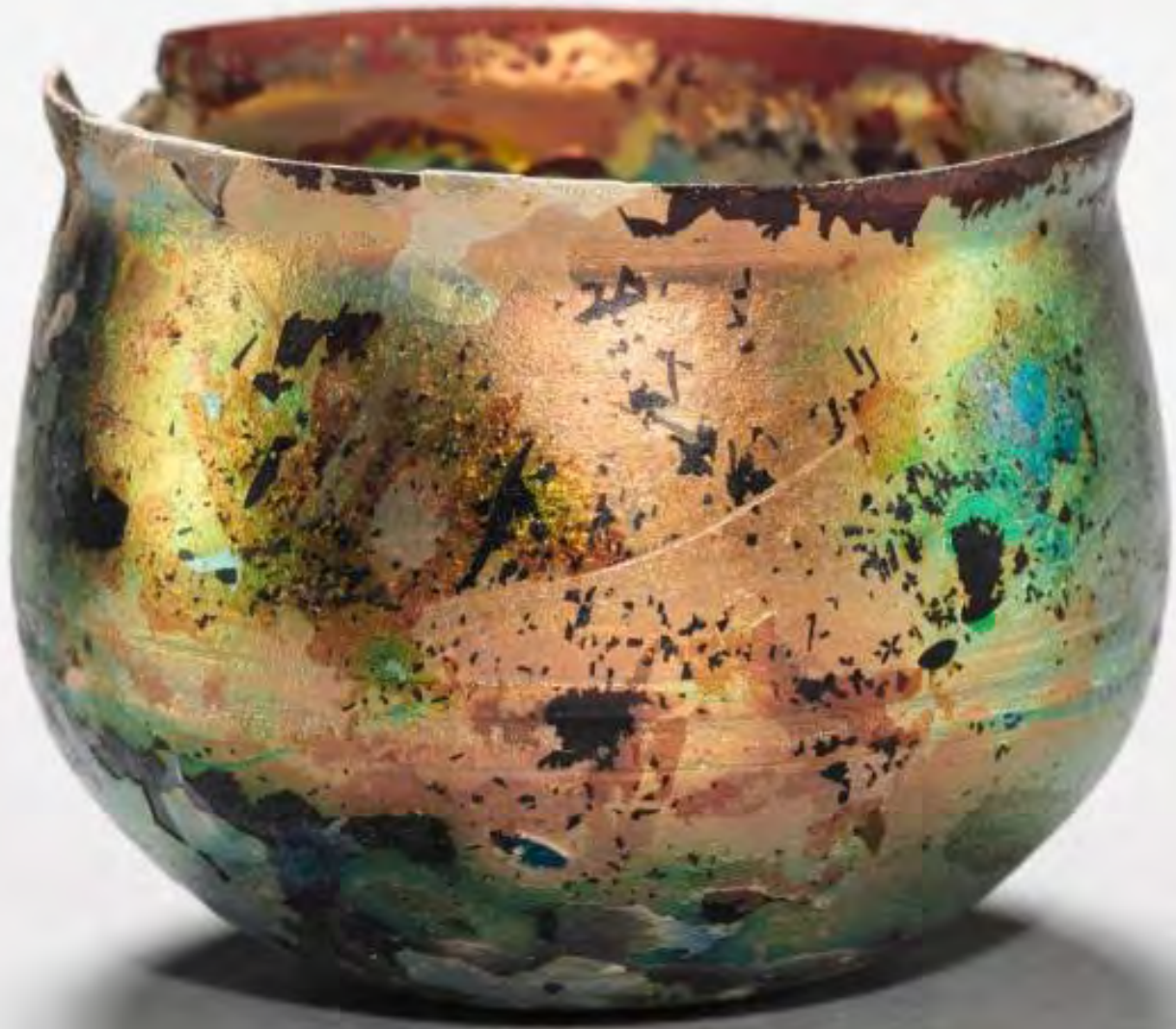




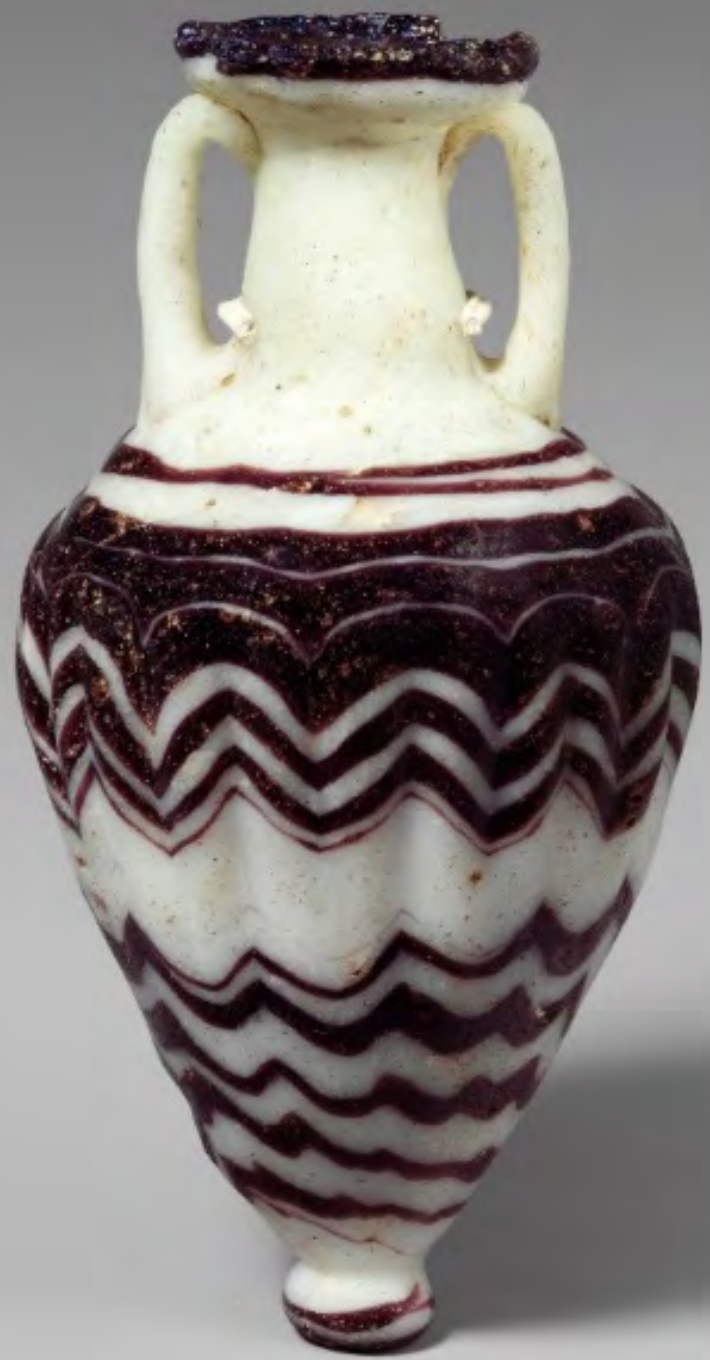

Figure 6. Greek, Eastern Mediterranean, Glass amphoriskos (perfume bottle), late 6th-5th century B.C., core-formed glass, overall: 4 3/4 $\times 2$ 7/16 in. $(12 \times 6.2 \mathrm{~cm})$. The Metropolitan Museum of Art. 


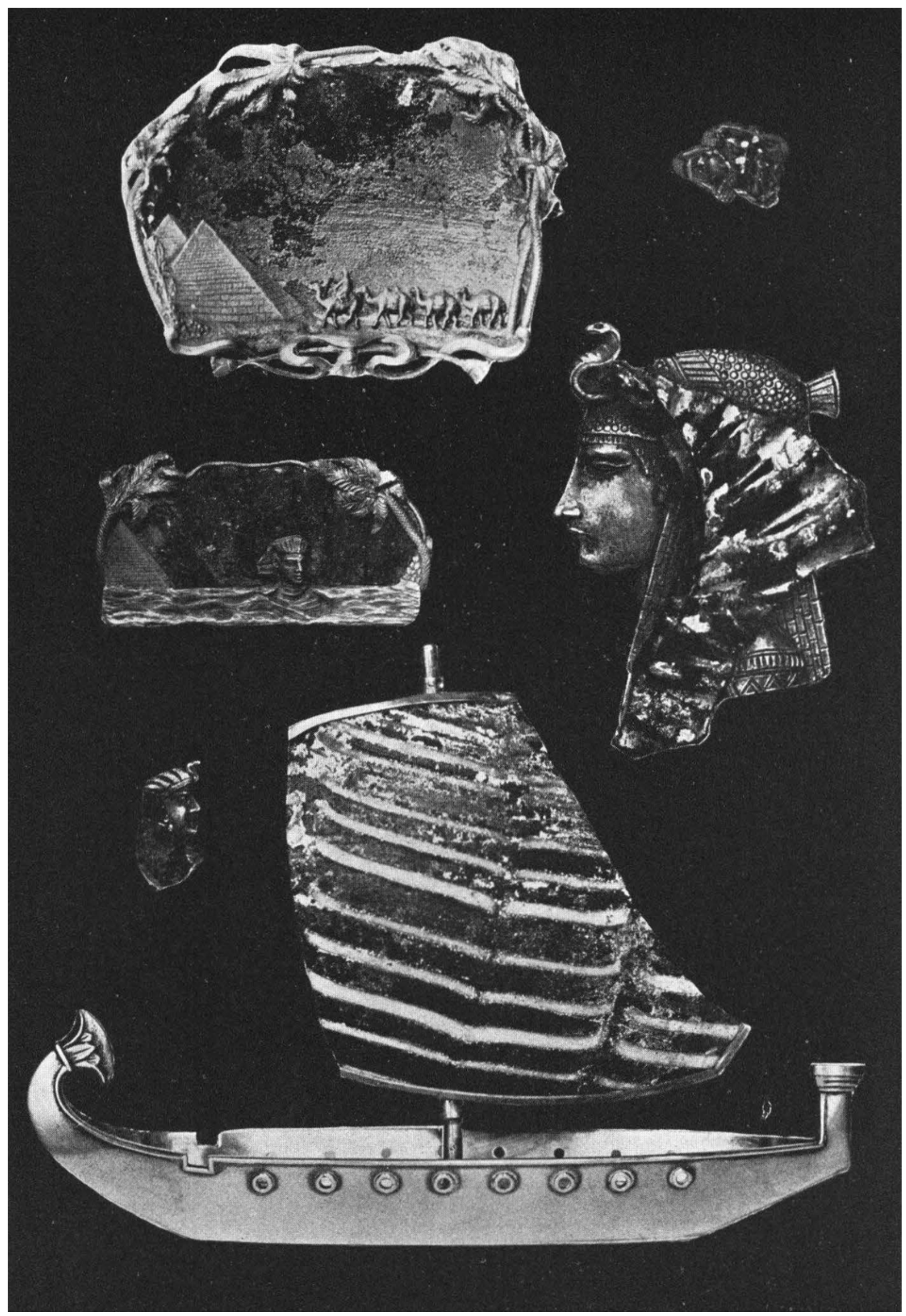




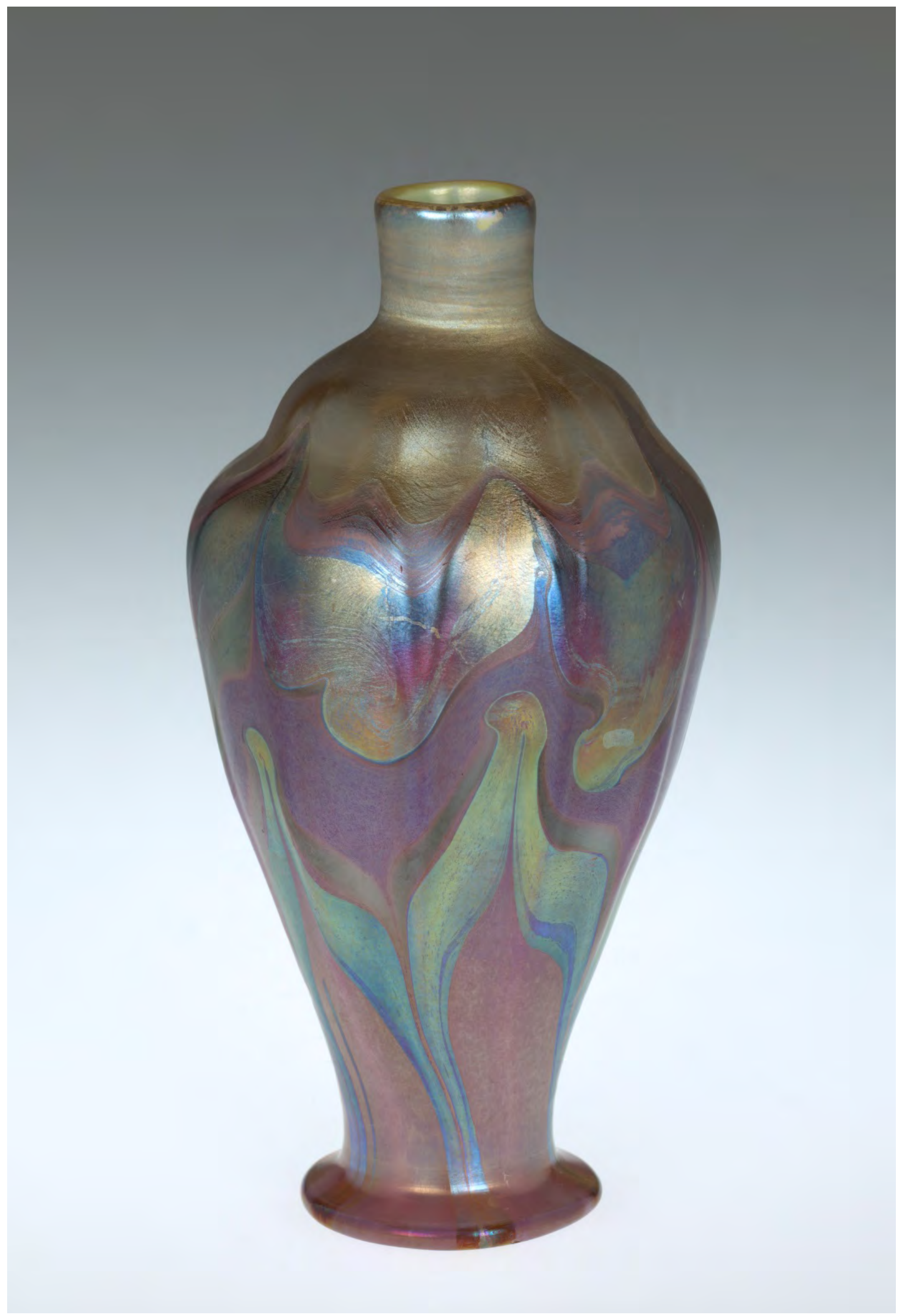




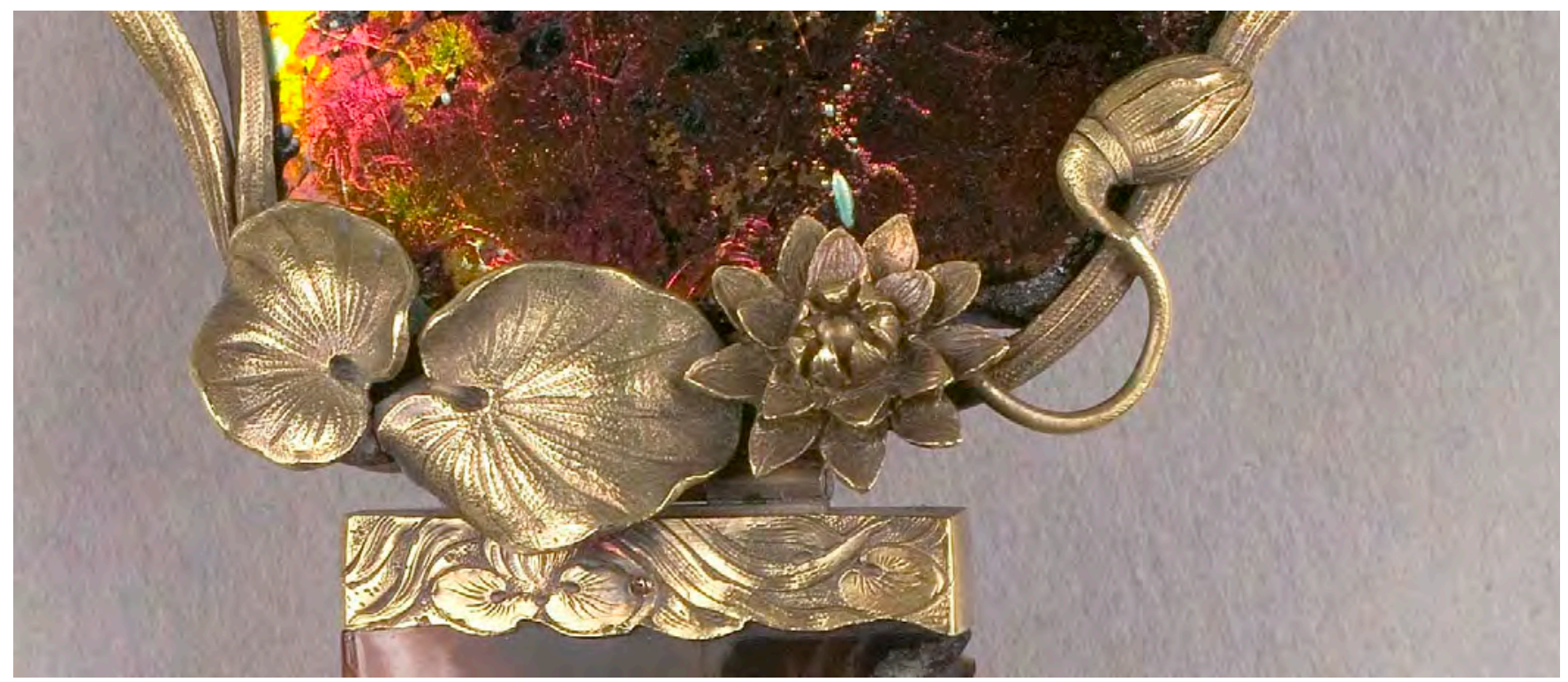

Figure 4. F. Walter Lawrence (American, 1864-1929) and Gustav Manz (German, 1865-1946), Ornamental Comb (detail), c. 1900, gold, ancient glass, gem stones, tortoiseshell, overall: $14.3 \times 5.8 \times 1.9 \mathrm{~cm}$ (5 5/8 × 2 5/16 × 3/4 in.). The Cleveland Museum of Art, Gift of the Trideca Society 2001.106 Photo credit: Courtesy of The Cleveland Museum of Art, Conservation Department.

Figure 8 [facing page]. Designed by Louis Comfort Tiffany (American, 1848-1933), made by Tiffany Studios (American, 1902-1932), Vase, c. $1905-10$, favrile glass, overall: $15.9 \mathrm{~cm}(61 / 4$ in.). The Cleveland Museum of Art, Gift of Ellen Wade Chinn, Elizabeth Wade Sedgwick and J. $\mathrm{H}$. Wade III in memory of their mother Irene Love Wade 1966.380. 


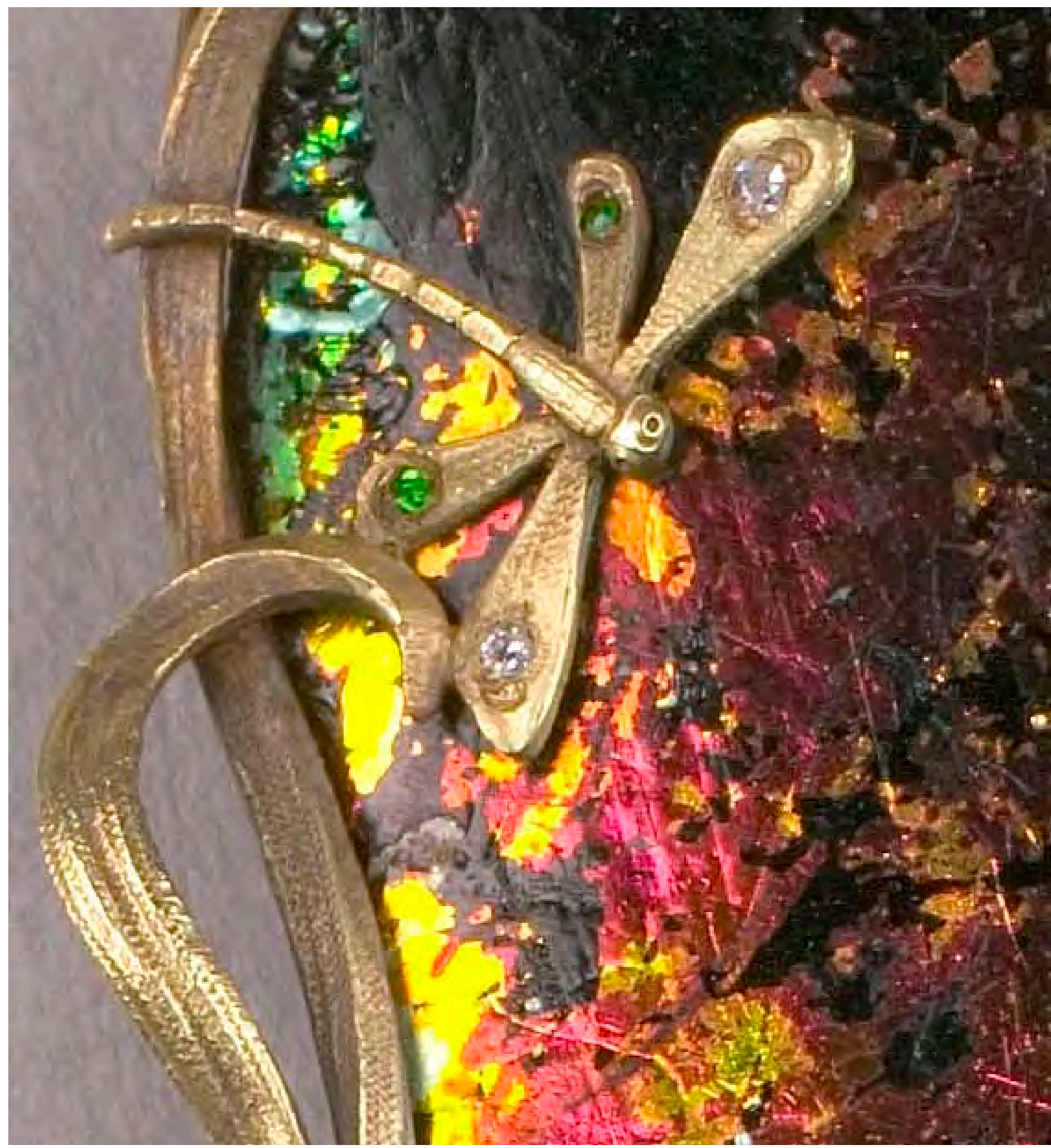

Figure 4. F. Walter Lawrence (American, 1864-1929) and Gustav Manz (German, 1865-1946), Ornamental Comb (detail), c. 1900, gold, ancient glass, gem stones, tortoiseshell, overall: $14.3 \times 5.8 \times 1.9 \mathrm{~cm}$ (5 5/8 × 2 5/16 × 3/4 in.). The Cleveland Museum of Art, Gift of the Trideca Society 2001.106 . Photo credit: Courtesy of The Cleveland Museum of Art, Conservation Department.

Figure 11 [facing page]. René Lalique (French, 1860-1945), Lily of the Valley Comb, c. 1900, horn, enamel and gold, overall: $15.4 \times 9.4 \times 3 \mathrm{~cm}(61 / 16 \times 3$ 11/16 x $13 / 16$ in.). The Cleveland Museum of Art, Gift of Mrs. A. Dean Perry 1981.49 (C) Artists Rights Society (ARS), New York/ADAGP, Paris. 


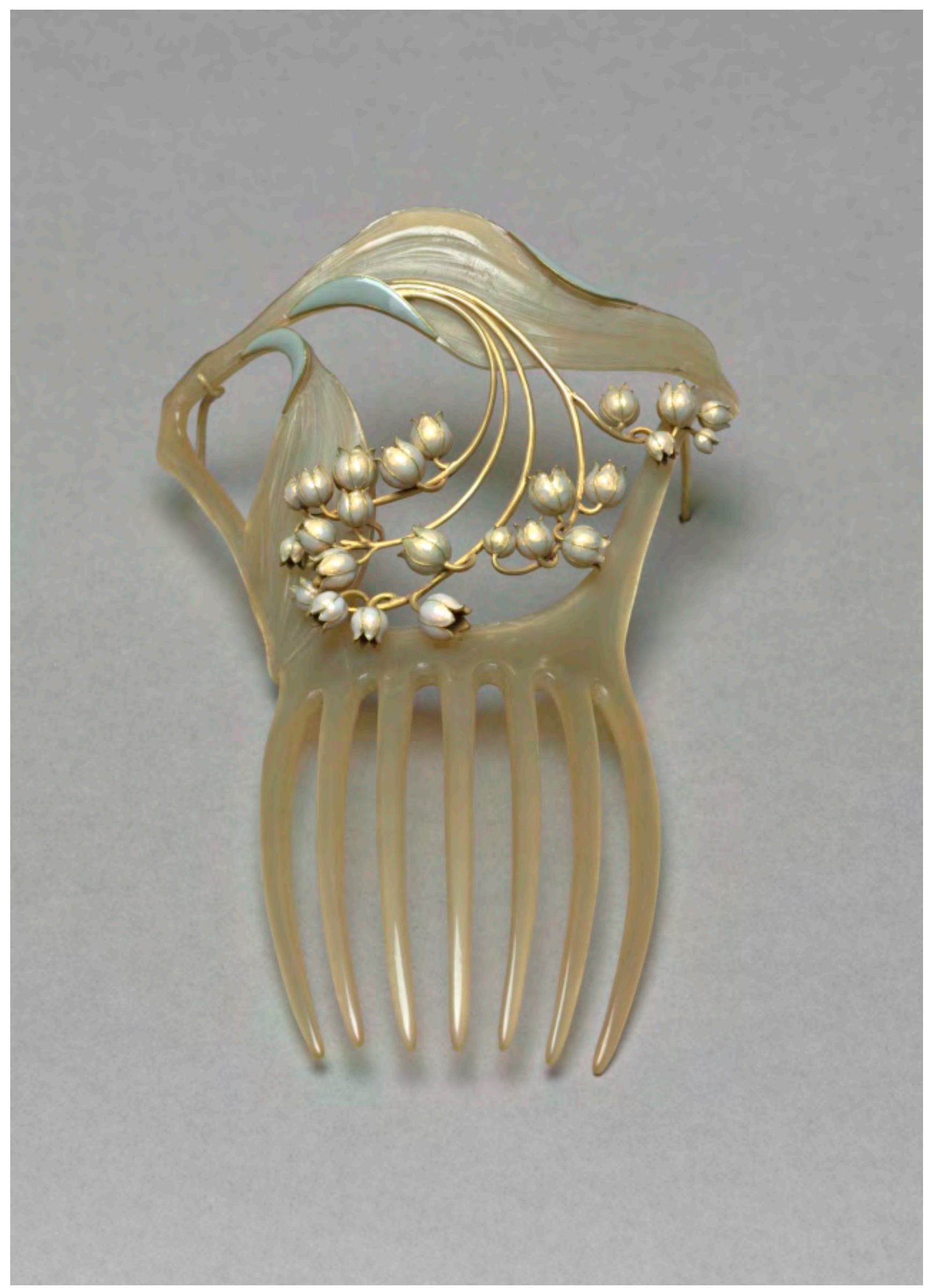




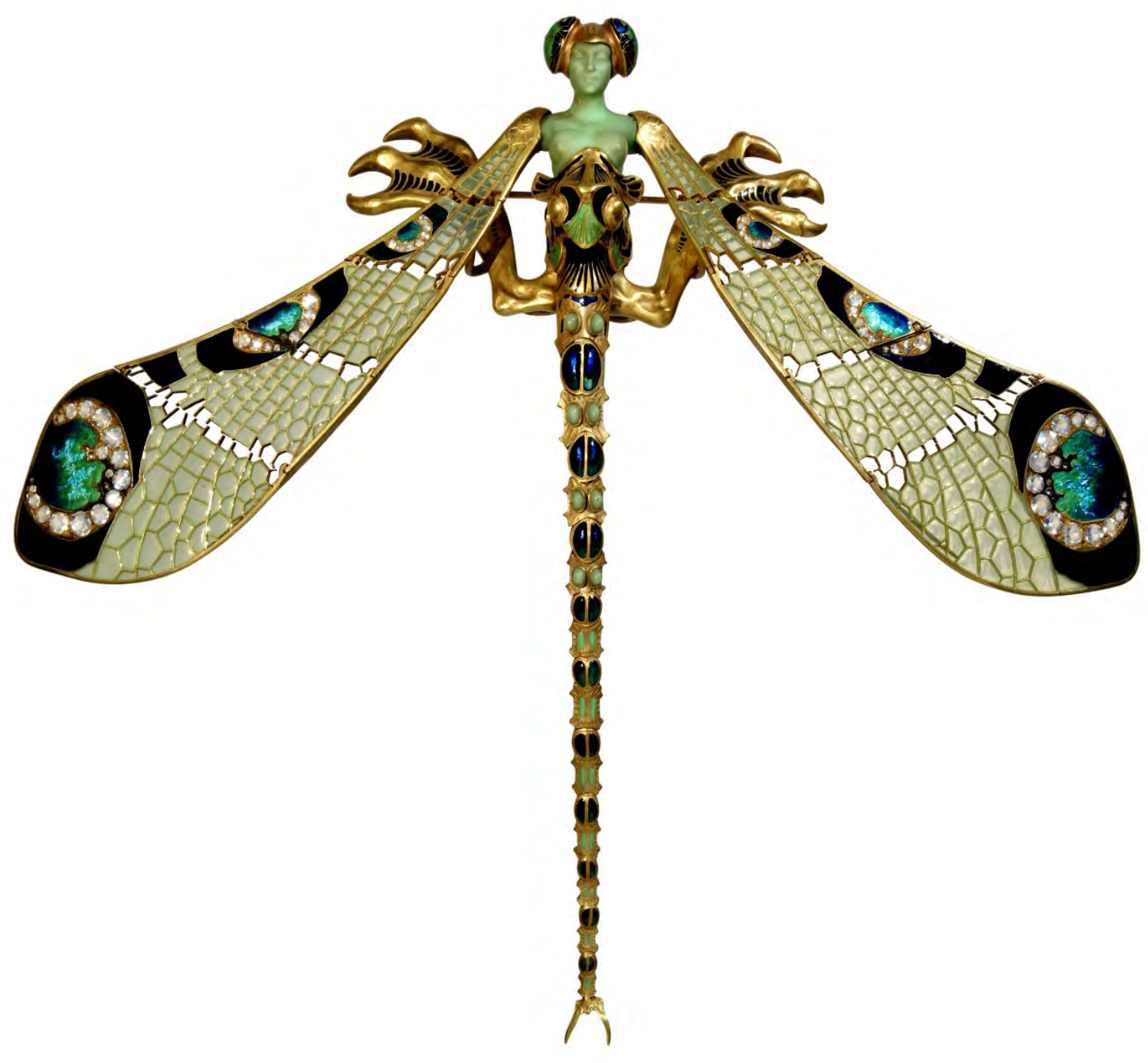

Figure 12. René Lalique (French, 1860-1945), Large Corsage Ornament in the Form of a Dragonfly, c. 1897-98, gold, plique-à-jour enamel, chrysoprase, chalcedony, moonstones and diamonds, overall: 23 x $26.5 \mathrm{~cm}$. Calouste Gulbenkian Museum, Lisbon, Portugal. 
Figure 13. S.I.P. 117/7, Les Bijoux, Peigne Ecaille \& Or, c. 1900, postcard with inscription in French, overall: $5.5 \times 3.5$ in. Collection of the author.
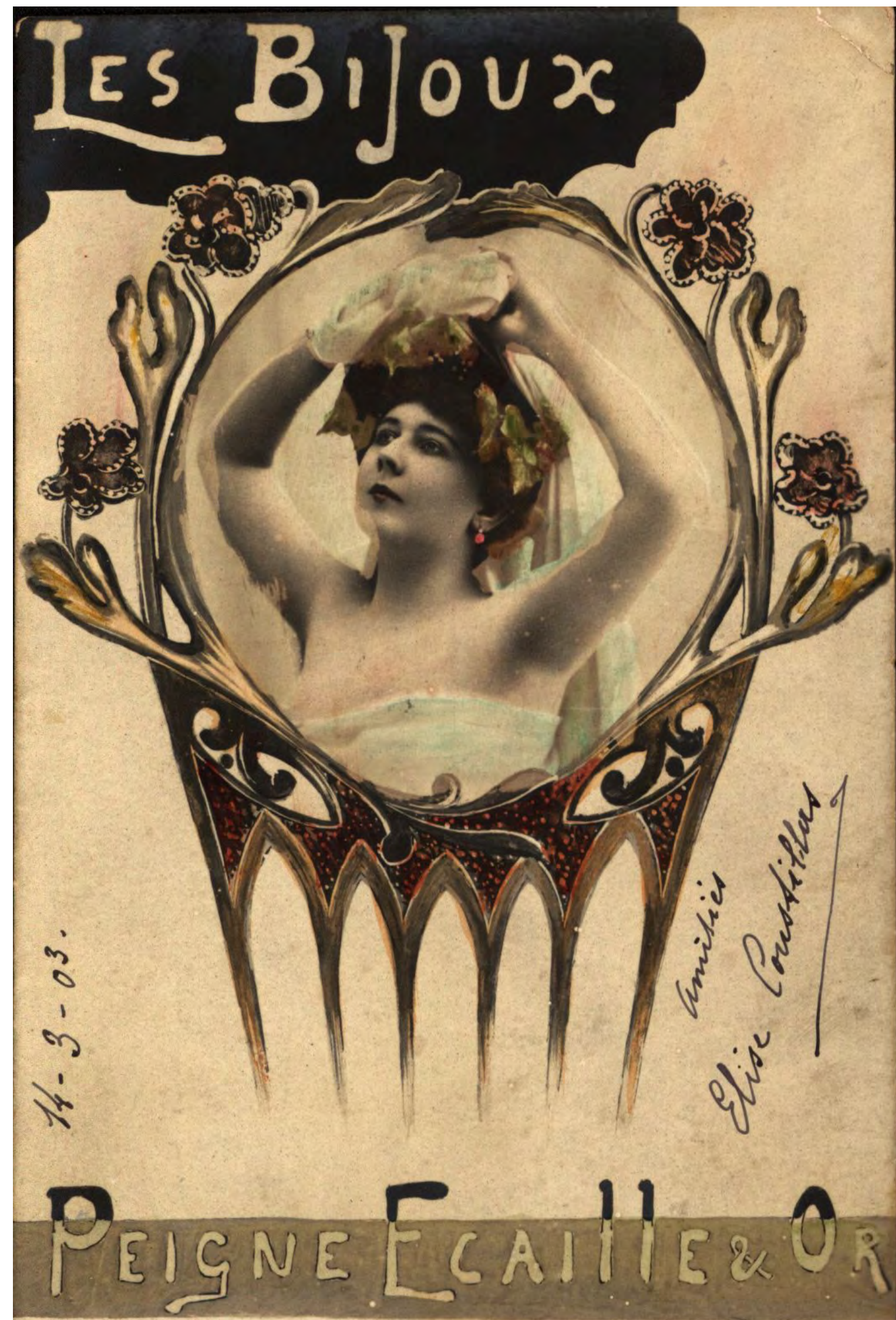
